\title{
The Independence of Research-A Review of Disciplinary Perspectives and Outline of Interdisciplinary Prospects
}

\author{
Jochen Gläser $^{1}$ (D) $\cdot$ Mitchell Ash $^{2} \cdot$ Guido Buenstorf $^{3}$ (D) $\cdot$ David Hopf $^{4}$. \\ Lara Hubenschmid $^{5}$ - Melike Janßen ${ }^{6}$ Grit Laudel $^{1}$ • Uwe Schimank ${ }^{7}$. \\ Marlene Stoll ${ }^{5}$ Torsten Wilholt ${ }^{4} \cdot$ Lothar Zechlin $^{8} \cdot$ Klaus Lieb $^{5,6,9}$
}

\begin{abstract}
The independence of research is a key strategic issue of modern societies. Dealing with it appropriately poses legal, economic, political, social and cultural problems for society, which have been studied by the corresponding disciplines and are increasingly the subject of reflexive discourses of scientific communities. Unfortunately, problems of independence are usually framed in disciplinary contexts without due consideration of other perspectives' relevance or possible contributions. To overcome these limitations, we review disciplinary perspectives and findings on the independence of research and identify interdisciplinary prospects that could inform a research programme.
\end{abstract}

Keywords Autonomy - Conflict of interest - Competition · Freedom of science · Science in dictatorships · Academy-industry collaboration · Social epistemology · Epistemic independence

Jochen Gläser

Jochen.Glaeser@tu-berlin.de

1 TU Berlin, Berlin, Germany

2 University of Vienna, Vienna, Austria

3 University of Kassel, Kassel, Germany

4 Leibniz University Hanover, Hanover, Germany

5 Leibniz Institute for Resilience Research, Mainz, Germany

6 German Centre for Higher Education Research and Science Studies (DZHW), Berlin, Germany

7 University of Bremen, Bremen, Germany

8 University of Duisburg-Essen, Duisburg, Germany

9 Department of Psychiatry and Psychotherapy, University Medical Centre Mainz, Mainz, Germany 
If you do not have the freedom to choose the subject of your research, the chances of discovering something of importance will already be limited. If your choice of methods is restricted as well, these chances are reduced even further. And if, at last, you are not allowed to disclose the results because they are inconvenient for some, many, or even all, it might be best for you to discard your research altogether-and for those who fund your research, too. This is what we have to prevent. (Hell 2019: 6, our translation)

\section{Introduction}

The independence of research is a key strategic issue in modern societies. Science has become a major source of wealth and is increasingly seen as a possible source of solutions to survival problems of contemporary societies. This has turned research capacity into a major base of power for actors in the 'knowledge society'; as a consequence, attempts to instrumentalize science and neglect its autonomy have grown. At the same time, the growth of science and the dynamics of its research technologies have turned it into a very expensive enterprise. It comes as little surprise that the question as to who should be able to influence research and how influence can be exercised without damaging the productivity and integrity of research becomes more important.

Current political struggles have made the independence of research take centre stage. The discourse on 'fake news' coincides with attempts by some governments to limit the independence of research (Goldman et al. 2017; Barnett and Wiber 2018; Rectors' Conferences 2018; Enyedi 2018). Even in countries with a broad societal consensus on the necessity to maintain academic freedom the actual extent of this freedom and the ways in which it should be maintained is subject to continuous negotiation, which is e.g. illustrated by legal challenges to some higher education reforms in Germany (Zechlin 2017). In analyses of research as a source of power, the independence of research from the state and industry is often seen as advantageous because political and economic interests are seen as 'corrupting' science (Lave et al. 2010), while independence from 'the public' (whatever it may be) and civil society actors is considered problematic because stakeholders with legitimate interests get disconnected from research (Brown et al. 2006; Frickel et al. 2010). Among researchers, there is an increasing concern about becoming dependent on incorrect or unreliable findings, whose growing number may disorient or slow down the knowledge production of scientific communities (Kern 2012; Byrne 2019). These concerns point to threats to the independence of research that emerge within the science system itself.

Dealing with the independence of research appropriately poses legal, economic, political, social and cultural problems for society, which have been studied by the corresponding disciplines and are increasingly the subject of reflexive discourses of scientific communities. Unfortunately, these perspectives are unevenly developed and insufficiently integrated. Problems of independence are usually framed in disciplinary contexts without due consideration of other perspectives' relevance or 
possible contributions. Therefore, the aim of this paper is to overcome the limitations of disciplinary perspectives by turning the independence of research into an object of interdisciplinary study. ${ }^{1}$

We begin by identifying relevant disciplinary perspectives and findings on the independence of research. Sociology specifies independence as the autonomy of actors, which it has considered mostly in dyadic relationships between researchers and their universities, industry the state or other actors. Economics conceptualises independence in a similar way but focuses on strategic actions in competitive situations. Its perspectives on goal formation and on the process of competing facilitate the investigation of changing conditions for independence, some of which are linked to intensifying and increasingly complex competitions in science. The most important perspectives on the independence of research developed by the Philosophy of Science are those of research ethics, the political philosophy of science, and of social epistemology. The perspective of Legal Studies considers academic freedom primarily as a personal defensive right, i.e. the right of the individual to reject incursions on its academic freedom by other actors. At least in the German case, which we exemplify here, the legal perspective can also be applied to organizations (mainly universities) as guarantors of academic freedom and to the level of the national science system whose independence is to be legally supported. The History of Higher Education and Science emphasizes that academic independence means different things under different historical circumstances, is granted academics to varying degrees, is not a necessary condition for high-quality research, and can be abused to produce scientifically based claims that benefit specific commercial or political interests. Self-reflections by research communities on the independence of their research address biases in research that are caused by conflicts of interests, which can be understood as researchers losing their independence. In addition, the dependence of researchers in the Global South on the (Northern) cores of their communities has been discussed by an increasing number of research communities.

We identify Interdisciplinary Prospects that could inform an interdisciplinary research programme, namely the social construction of independence and the relationship between independence and the content of research. Finally, we draw some Conclusions about the benefits of the concept 'independence of research' as a focus of interdisciplinary studies.

\section{The Independence of Research: Disciplinary Perspectives}

In the most general sense, the independence of research refers to the extent to which actors in science are free from influences that alter their choices. Actors are completely independent if there are no such influences, or if they are able to resist such influences. They are completely dependent if other actors make all their choices for

\footnotetext{
1 This paper is the result of a string of discussions the authors had among themselves and with participants of several workshops. We are particularly grateful to Martina Franzen, Fabian Hattke, and Simone Rödder, who contributed ideas in the discussion process.
} 
them. Neither extreme is likely to occur empirically, i.e. independence is always a matter of degree. It is important to note here that there is no reason to assume that beyond a minimum that guarantees the functioning of the science system, more independence is always better. Indeed, it is also important to consider what researchers themselves do with their independence that might constrain research options within the system.

This very general idea of independence has been specified by the disciplines for investigations in their respective conceptual frameworks. Hereinafter, we consider how sociology, economics, the philosophy of science, legal studies and the history of science conceptualise the independence of research, which problems of independence they address and which gaps in disciplinary knowledge exist. We conclude this section by an account of reflexive discussions of threats to independence by scientific communities in the social sciences, sciences, and medicine.

\section{Sociology}

Sociology specifies independence as the autonomy of actors. ${ }^{2}$ Actors are never fully in control of their own conditions of actions because they are always embedded in sets of relationships with other actors and thus interdependent. Within these constellations of interdependence, some actors intend to change others' behaviour by exercising influence. Autonomy refers to an actor's handling of such influences and is considered as the degree of control over the formation of goals and the choice of approaches to achieving them that remains with an actor who is influenced by others (Gläser and Schimank 2014). ${ }^{3}$

Autonomy thus is a property of all actors in the science system including individual researchers, research groups, research organisations (e.g. universities), and funding agencies. Although studies of these types of actors have rarely considered their autonomy explicitly, several recurrent topics of science studies can be interpreted as addressing the autonomy of actors in science (Table 1). These topics mostly consider a specific relationship and the effects of dependencies on research.

Among the various actors influencing researchers, companies have received the most attention. Researchers investigating the influence of pharmaceutical companies on drug studies found "that study outcomes were significantly different in privately funded versus publicly funded drug studies" (Krimsky 2013: 569; for the evidence see e.g. Bekelman et al. 2003; Schott et al. 2010a, b). One of the causes of the funding effect is bias, which is defined as "the use of a method, data collection, data analysis, or interpretation of results that, in the consensus view of scientists of a discipline, tends to yield results that distort the truth of a hypothesis under consideration"

\footnotetext{
${ }^{2}$ For an alternative perspective, which considers the autonomy of social systems, see Luhmann (1995) and Stichweh (2014).

3 This idea can be extended to sets of interdependent actors such as markets or communities. The autonomy of such an actor constellation could be understood as the extent to which external dependencies leave the way in which this actor constellation 'functions' (its basic social order) intact (Gläser and Schimank 2014).
} 
(Krimsky 2013: 568). Furthermore, collaboration with industry was found to slow the diffusion of new knowledge but not to limit it (Evans 2010a, b). Empirical studies also confirmed that collaboration with industry makes researchers withhold their data from colleagues, although other reasons like the wish to maintain a competitive advantage may lead to the same result (Blumenthal et al. 1997).

Dependencies on the state are rarely discussed. Recent studies focus on the alignment of state and industry interests and discuss effects of state influence similar to those of industry influence, with the interesting additional twist of the production of ignorance (Frickel et al. 2010). An interesting gap in studies of researchers' dependence on the state concerns the exclusion by the state of its own or foreign researchers from the communication within their scientific communities through travel restrictions (but see Varma and Sabharwal 2018).

Effects of researchers' and universities' dependence on the military, which merit separate treatment due to the specific interests and governance tools of this sector of the state, have been mostly investigated from a historical perspective (see below, History of Higher Education and Science), not least due to the problems of gaining access (Rappert et al. 2008: 731-732). A sociological analysis shows how weapons

Table 1 Foci of science studies related to the autonomy of actors in science

\begin{tabular}{|c|c|c|}
\hline $\begin{array}{l}\text { Actors whose } \\
\text { autonomy is } \\
\text { considered }\end{array}$ & Influence exercised by & Effects discussed \\
\hline \multirow{7}{*}{ Researchers } & Industry & $\begin{array}{l}\text { Thematic changes, changes in quality, biases towards } \\
\text { clients' interests such as publication bias, creation of areas } \\
\text { of ignorance, diffusion of new knowledge, secrecy }\end{array}$ \\
\hline & State & $\begin{array}{l}\text { Thematic changes, biases towards the state's interests, } \\
\text { creation of areas of ignorance, diffusion of new knowledge }\end{array}$ \\
\hline & Military & $\begin{array}{l}\text { Research topics externally defined, severe restrictions to } \\
\text { communication, exclusion from scientific communities }\end{array}$ \\
\hline & Civil society actors & $\begin{array}{l}\text { Thematic changes, changes of research approaches (for } \\
\text { instance, respect for animal rights) }\end{array}$ \\
\hline & $\begin{array}{l}\text { Scientific communities } \\
\text { - through peer review }\end{array}$ & $\begin{array}{l}\text { - Thematic changes, e.g. towards mainstream research or } \\
\text { risk avoidance }\end{array}$ \\
\hline & $\begin{array}{l}\text { - through North-South } \\
\text { collaboration }\end{array}$ & $\begin{array}{l}\text { - Impact of North-South collaborative research funding on } \\
\text { topic selection by researchers from the South, limited } \\
\text { recognition of Southern researchers, exclusion from } \\
\text { scientific communities }\end{array}$ \\
\hline & Universities & $\begin{array}{l}\text { Changes in publication behaviour, changes of collaboration } \\
\text { patterns }\end{array}$ \\
\hline $\begin{array}{l}\text { Funding } \\
\text { agencies }\end{array}$ & $\begin{array}{l}\text { State and scientific } \\
\text { communities }\end{array}$ & $\begin{array}{l}\text { Degree to which funding agencies can develop independent } \\
\text { strategies or are 'captured' by scientific communities or } \\
\text { other actors }\end{array}$ \\
\hline Universities & State & $\begin{array}{l}\text { Degree to which universities can develop independent } \\
\text { strategies, changes in research profiles }\end{array}$ \\
\hline
\end{tabular}


researchers consider their secure jobs and research funding as well as their freedom to choose approaches to problem solving as sufficient compensation for their lack of choice of research problems and severe restrictions to their communication (Sutton 1984). This and other studies indicate shifts of researchers' identities that make their goals coincide with the expectations of their sponsors (Gusterson 1995, 2003).

Another, more recent line of research investigates the exercise of influence on research by civil society actors. Its focus is on the channels available to these actors and the ways in which civil society actors (e.g. social movements or patient organisations) can influence the directions or approaches of research (Brown et al. 2006; Panofsky 2011). It is important to note that some of these actors, namely many patient organisations, are themselves dependent on pharmaceutical companies that may fund, steer and sometimes even found them (Moynihan and Bero 2017).

Influences from scientific communities are included here because the analytical approach to independence advanced in this paper is not limited to influences from outside science, even though this is the common understanding among scientists, throughout society and particularly in legal contexts. Among these influences, peer review has been extensively studied, and has been found to induce risk avoidance and mainstream research (Chubin and Hackett 1990; Travis and Collins 1991: 336). However, more recent studies of funding programmes for 'breakthrough' research suggest that these effects can be avoided if reviewers are instructed accordingly (Heinze 2008; Luukkonen 2012). Another dependence relation under investigation is the dependence of researchers in the Global South from those in the Global North. International funding appears to force some researchers in the Global South to adapt their research topics to expectations of funding agencies or preferences of collaborators in the Global North (Gaillard 1994; Moyi Okwaro and Geissler 2015). Studies by Rafols and colleagues point to divergent priorities of researchers in the Global North and the Global South, which create situations in which researchers must adapt their research topics to priorities of the Northern elites if they want to become part of their communities' global discourses (Wallace and Rafols 2018; Ciarli and Rafols 2019). The perception of this tension has led to discussions about centre-periphery relationships in several scientific communities (see below, Self-Reflections by Scientific Communities).

The dependence of researchers on their universities has been investigated mostly in the context of evaluation systems for research performance affecting the autonomy of researchers. This research yields only indirect hints on effects, which is mainly due to the problems of causally ascribing changes to evaluations (Gläser and Laudel 2016: 129-134).

The shift from recurrent funding of research to a split funding mode of recurrent funding for universities and competitive project funding for researchers triggered an interest of science studies in the role of funding agencies, which became important actors in the science system (Rip 1994). Comparative studies found the autonomy granted to funding agencies by the state to vary considerably across national science systems (Braun 1998). The causal link between this varying autonomy and the funding agencies' impact on researcher autonomy has not yet been studied.

Finally, higher education studies have discussed the impact of higher education reforms on the autonomy of universities (Schimank 2005; Enders et al. 2013). The 
numerous analyses, which mostly focus on European higher education systems, have yet to provide a clear picture of how 'New Public Management' (NPM) reforms change university autonomy. Although the various changes in higher education laws formally enhance university autonomy, the picture is much less clear for the factual autonomy of universities (Capano 2011; Enders et al. 2013; Whitley and Gläser 2014).

The strong focus of sociological studies on dyadic relationships between actors has left several aspects of the independence of research underexplored. First, the processing of multiple dependencies has rarely been empirically investigated in science studies. Recently, it has been taken up by the "authority relations"-perspective (Whitley et al. 2010; Whitley et al. 2018) but there is still far too little empirical research on the integration of dependencies in the situation of researchers. Thus, the sociology of science is not yet able to answer the question as to how researchers respond to the multitude of influences on their independence. What is the resultant of all the influences that were studied in isolation? In particular, under which conditions can research paradoxically gain an increased independence as a result of a multitude of dependencies on diverse actors?

Secondly, there is also insufficient research on the impact of competition on the autonomy of researchers. Funding competitions are often established as means to influence researchers, e.g. to make them improve research quality or turn to particular topics. They may also be institutionalised as means to distribute scarce resources. So far, no attempt has been made to distinguish different kinds of competition and their impact on the autonomy of researchers. What does the participation in an evergrowing number of overlapping competitions (Krücken 2019) do to the independence of researchers?

The task of empirically establishing changes in the autonomy of an actor as an effect of influences implies two interesting methodological challenges. Our review of sociological studies demonstrated the importance of determining not only the formal autonomy of an actor-the autonomy granted by formal institutions-but also the actual autonomy an actor has in specific situations. A second methodological challenge arises with the attempt to determine the aggregate effects of researchers' individual adaptation to influences on their research. Although we know that researchers are influenced and can be confident about some of the individual-level effects, the ways in which these micro-level effects lead to macro-level changes in knowledge are yet unknown because until now we lack the methods to identify and causally ascribe macro-level epistemic changes.

\section{Economics}

Economics studies actors engaged in strategic, often competitive interactions with one another. Among these competitions, the dominant focus is on markets, a focus which entails the assumption that actors have at least some autonomy. The study of actors embedded in competitions implies two perspectives that can be applied to the independence of research, namely the study of influences on goal formation and the study of the process of competing. 


\section{Goal Formation}

The formation of goals by actors in science can be considered as self-organised within scientific communities, occurring in a framework of commercialisation (industrial application of science), or occurring within an impact framework of general societal usefulness. Economics has studied goal formation of researchers with a special focus on effects of commercialisation on the individual level. These research interests and findings overlap with science studies' investigation of academy-industry collaboration. Topics include the relationship between patenting and publication activities as well as the impact of academy-industry relationships on thematic changes (towards more applied research) and on secrecy or delayed publication (Azoulay et al. 2009; Hottenrott and Thorwarth 2011; Czarnitzki et al. 2015). The impact of commercialisation expectations on universities has not received comparable attention.

There are no findings yet on the consequences of a generalised societal impact expectation on researchers or research organisations, probably because these expectations have been inscribed in evaluation systems only recently. Thus, it is not clear yet whether causal effects can be identified at all. However, the expectation to identify societal impact raises a fundamental question about the public funding of science because from the perspective of economics, the main justification for public funding of science is that applications and beneficiaries of research are not yet identifiable (Nelson 1959).

\section{Process Perspective}

The process perspective asks how being engaged in competitions with each other affects the independence of researchers. This question addresses a strong overlap of the sociology of science and the economics of science, which both study competitions. Applying sociological theories of exchange to science, sociologists formulated models of science being based on an exchange of findings for recognition (Hagstrom 1982) or competent feedback (Storer 1966). Other approaches resembled models of capitalist accumulation (Bourdieu 1975; Latour and Woolgar 1982). These ideas were later taken up by the "new economics of science" (Dasgupta and David 1994; David 1998a, b), which describes science as a "winner takes all"-competition in which only the first contributor of new knowledge is recognized.

A second, probably more important basis for the study of competition in science is the increasingly competitive allocation of resources for research. These competitions differ in the degree to which they are endogenous to the scientific community or installed by external actors. Many competitions for resources combine endogenous and exogenous elements, while others are exogenous only. The latter competitions differ from the traditional competition for recognition in science in that they may be considered as contests where contestants compete for a given prize in a zero-sum game. An extensive literature in economics shows that contests induce societally wasteful "rent seeking" behaviour and often are not in society's best interest (Tullock 1980; Hillman and Samet 1987; Van Long 2015). 
The process perspective provides opportunities to explore the transfer of ideas from the study of markets and innovations to the multiplying and changing competitions in science. The number, kinds, and scopes of competitions in science have increased, and are still increasing in many countries, in the context of NPM governance reforms. Some competitions are based on new measures to compare contestants. For example, quantitative measures of reputation and performance are increasingly used, which may trigger adaptive behaviour and discriminate against certain types of research. At the same time, traditional competitions e.g. for project funding create increasing pressure on participants because success rates keep decreasing. Again, there is an interesting overlap with sociology's interest in "quasi-markets" in higher education, i.e. in competitions that resemble markets to some extent but do not meet the definition of markets (Le Grand and Bartlett 1993; Barr 1998; Dill et al. 2004; Teixeira et al. 2004).

Questions about competitions in science that may be asked from an economics perspective include:

- Under which conditions does competition in science increase the diversity of research by stimulating differentiation? This question is based on the observation of product differentiation in markets for goods with few suppliers, who strategically decide about product differentiation. This model might be applicable to competitions in science with relatively few suppliers (e.g. universities). The relevance of product differentiation for competition in science has yet to be determined.

- What role does the competition of funding agencies play for competition in science? Monopsony (markets with a single buyer) also occurs in competitions for research funding, e.g. in performance-based funding of universities and in funding competitions in which all competitors can apply with only one funding agency. Economics has found that monopsony leads to an exploitation of suppliers (e.g. workers in labour markets). The impact of monopsony on the diversity of research, competition and innovation has not yet been studied.

- Do path dependencies and lock-ins occur that reduce diversity and innovation? In competitions with a homogenous demand, suppliers who meet this demand become rewarded, which increases their ability to outcompete alternative approaches. Cumulative advantages and network effects may strengthen mainstream research and reduce diversity.

- How do new competitors enter a funding competition, and what role do they play in these competitions? In markets, radical innovations are often introduced by new suppliers. These observations raise questions about 'barriers to entry' in competitions in science, how they are related to the independence of researchers/ competitors, and possible effects on scientific innovations.

- How does increasing competition affect the openness of science? The inherent conflict between science being based on free access and autonomous utilisation of scientific findings on the one hand, and being overlaid by market structures and competitions that suggest secrecy, on the other hand, has primarily been studied with regard to the impact of intellectual property rights (patents, material transfer agreements) covering research inputs (Murray and Stern 2007; Murray 
et al. 2016; see also Section 2.1) and secrecy (David 1998b). The possible contradiction between open data policies and policies increasing the competitiveness of the science system remains to be investigated.

\section{Philosophy of Science}

While 'independence' is not a technical term in philosophical discussions about science, philosophy of science has developed a multitude of perspectives that are related to the independence of research. Among these, the contributions from research ethics, from the political philosophy of science and from social epistemology stand out as most seminal.

In research ethics, independence plays a role in the discussion of misconduct, bias and professional integrity. Research ethics as a type of professional ethics starts from the assumption that the social role defined by a particular profession is associated with particular kinds of role responsibilities which in turn require the implementation of specific norms or ethical principles. Specific principles suggested for research ethics include striving to eliminate personal biases, as well as non-interference with scientists' opportunities to pursue new avenues of research and criticize existing views (Resnik 1998, 2007, 2009). The exact relation of such ethical imperatives with different forms and levels of independence in science awaits further philosophical research.

Within the political philosophy of science, independence figures in the form of debates about scientific freedom. Wilholt $(2010,2012)$ identifies and discusses three types of argument.

The first is an argument from autonomy, based on the thesis that humans must be free to investigate the world because it is one of the basic prerequisites of a selfdetermined life to be able to freely gain knowledge. This very basic argument provides grounds for opposing interference with an individual's efforts at knowledge generation. However, additional reasons are needed to defend the claim that principles of freedom and independence ought also to hold within a collective (statesponsored) and coordinated enterprise of research.

Such are provided by the epistemological argument (in Wilholt's terminology), which states that to allow individual scientists the widest possible freedom is the most efficient way to ensure that the sciences give us as much as possible of the kind of knowledge that we as a community are hoping to get from them. Classic articulations of the argument (like Mill's, 1992 [1859]) typically start from a reference to the fallibility of the human quest for knowledge. It is impossible to decide in advance which theory, which methodological approach, which research project is the one to achieve the next major breakthrough — and which one is a wrong track or a dead end. An inquiring community should therefore never put all its eggs in one basket (or only few baskets). A variety of different approaches creates the best possible conditions for success. And this variety, so the argument goes, can best be created by granting individual freedom. From the perspective of contemporary social epistemology, this problem is related to the problem of describing the roles of different dimensions of freedom and independence for an efficient distribution of 
cognitive labour within a research community (Kitcher 1990; Holman and Bruner 2015).

The third argument on Wilholt's count is a 'political' argument according to which the purpose of freedom of research is to guarantee the political independence of the sciences. It is widely recognized that the formation of political preferences is already part and parcel of the democratic process. Its preconditions therefore include independent sources of knowledge. In a world in which we have to rely increasingly on the sciences for information on politically relevant substantive issues, their political independence becomes a significant factor.

Other authors have emphasised how science should be dependent on societal values in a democratic society, and how the integration of the value of knowledge with moral and political values could be achieved (Kitcher 2001; Kourany 2010). Kitcher proposes, as an "ideal of well-ordered science", that priorities in research ought ideally to be set like a collective of well-informed discussants would set them in an ideal conversation situation. The way to come close to this ideal, he argues, is not to give free reign to scientists but to implement social procedures that approximate the operation of such collectives, in the form of groups of citizen representatives (Kitcher 2011).

In the area of social epistemology, independence is discussed as a functional prerequisite of objectivity. The formerly influential idea that objective science needs to be independent from all extra-scientific value interests has come to be gradually abandoned. Of particular influence in this regard have been arguments that methodological decisions in the inductive sciences are always incomplete without considerations of how serious a mistake would be, and that therefore scientists are morally obligated to take the consequences of accepting a hypothesis into account (Douglas 2000, 2009) or, in a variant of the argument, that they need of necessity do so lest methodological choices remain underdetermined (Wilholt 2009; Biddle and Winsberg 2010). The debate has also focused on the question whether certain kinds of values can be considered as 'epistemic' and delineated from more problematic value influences such as ones of a moral or political character (Rooney 1992; Longino 1996; Steel 2010).

There has also been a shift towards a more social account of objectivity. Objectivity is not considered at the level of the individual researcher anymore because it seems difficult to explain in what sense individual researchers can be objective. Instead, the discussion focuses on procedures by which collective-level objectivity is achieved. Thus, Helen Longino (1990) identifies transformative mutual criticism as the core of procedural objectivity and investigates the kinds of features that epistemic communities must have in order to achieve it. In this context, scientific pluralism is considered as important for collective-level objectivity, which can be linked to independence as a condition for pluralism. Collective level epistemic effects of social rules have recently also begun to be studied by philosophers using formal models and computational methods. Kummerfeld and Zollman (2016) have attempted to show that in a completely autonomous scientific community scientist may become conservative and risk-averse, thereby arguing that exogenous institutional constraints may be beneficial for scientific progress. 
Philosophers concerned with social epistemology (often combining this perspective with aspects of the political philosophy of science) have often worked with a case-based methodology and examined extra-scientific influences within particular, defined areas such as the increasing commercialisation and commodification of scientific research (cf. Radder 2010), the politicised arena of climate science (Frisch 2013; Winsberg 2018), the interplay between methodology and social interests in medical science (Solomon 2015; Stegenga 2018), or the contested knowledge claims of environmental science (Elliott 2011).

Philosophical research on all these topics is ongoing and likely to contain more fuel for future debates. Controversial questions that are likely to inform philosophical research related to the independence of scientific research in the near future include the following.

- Perceived independence seems to be an important factor contributing to the trust invested into research results by the public. At the same time, it has been suggested that to maintain credibility in the face of an apparent gradual loss of public trust in science (and other institutions of the open society), science needs to become more responsive and accountable to public needs. Thus, which is the key to science's credibility: more independence, or less?

- Given the emerging consensus amongst philosophers of science that the valuefree ideal for scientific research is unrealisable, does this mean that the independence that is necessary for epistemically productive research should also include a free play of value influences? Or is there a way to delineate acceptable from unacceptable value-based methodological decisions (a task that has been dubbed the "New Demarcation Problem")? The urgency of this problem has increased since 'researcher degrees of freedom' have started to be linked to questionable research practices (Simmons et al. 2011).

- Both the epistemic and the political benefits of scientific independence are linked to its assumed tendency to facilitate pluralism and a diversity of approachesincluding a propensity to foster mutual criticism, dissent and controversy. But recent research has drawn attention to the phenomenon of 'manufactured dissent' in the sense of efforts (motivated by particular interests) to undermine scientific knowledge claims by means of producing apparently scientific contrarian views (Oreskes and Conway 2010). This has prompted some philosophers of science to attempt to articulate criteria by which to identify 'epistemically detrimental dissent' (Biddle and Leuschner 2015), while others insist that all controversy must be welcomed regardless (de Melo-Martín and Intemann 2018). So, are there limitations to the epistemic and political benefits of pluralism and dissent and is it possible to delineate them on principled grounds?

\section{Legal Studies}

Reconstructing the perspectives of legal studies on the independence of research in an interdisciplinary context faces two main challenges. First, the law does not state empirical facts but formal normative positions. It is codified in highly abstract texts of law that become concretised in their application to cases by jurisdiction. 
Nevertheless, the law needs to be linked to the social reality lest it loses the capacity to influence societal processes. Legal studies therefore link the normative statements of the law to its empirical preconditions and effects. It is this link between the 'ought' of the legal structure and the social reality that makes possible the integration of legal studies in interdisciplinary approaches with the social sciences and humanities.

Secondly, most legal structures are national structures, which is why legal studies belong to the fields with the strongest national orientation. Legal scholars predominantly communicate within their countries on these countries' laws. There is a growing interest in internationally comparative legal studies because international comparisons are instructive for the evaluation of a formal normative structure against its empirical preconditions and effects, and would support the search for alternative legal solutions. However, international comparisons require a national legal system as a starting point. This is why in the following we present the specific perspective of German legal studies on the independence of research as an example and possible starting point for international comparisons and for the exploration of interdisciplinary connections. Conducting an international comparison is beyond the scope of this paper and remains an important task for future research (see below).

\section{Independence of Research in the Law: The Case of Germany}

German legal studies conceptualise the independence of research as "freedom of science" (in the all-encompassing German sense of "Wissenschaft", i.e. including the social sciences and humanities). This freedom is encoded in Art. 5 III of the German constitution with the statement "Arts and sciences, research and teaching shall be free. The freedom of teaching shall not release any person from allegiance to the constitution". The constitutions of some of the federal states additionally guarantee the freedom of higher education institutions or their right to self-governance.

The fundamental right of freedom of science can be assigned to three dimensions or levels of aggregation (Table 2). First, there is the understanding of the freedom of science as a personal defensive right ("status negativus"), i.e. the right of the individual to reject incursions, by the state or (to some extent) private actors (Britz 2013: RN 11; Weingart 2014). The rulings of Germany's constitutional court add to that defensive right the positive right ("status positivus") to have means for the conduct of free research and the task of the state to enable free science by providing personal, financial and organisational means (BVerfGE 35, 79/114f; Weingart 2014). ${ }^{4}$ Although this interpretation is still formulated as a personal right to freedom of science, it also introduces as a second dimension an organisational understanding of the freedom of science. This dimension mainly implies the obligation of the state to provide an adequate organisational structure for free science. However, this organizational-level guarantee of freedom for higher education institutions is only

\footnotetext{
${ }^{4}$ We apply the reference style for German court rulings. BVerfGE $35,79 / 114$ f. stands for Rulings of the Bundesverfassungsgericht (Federal Constitutional Court), Volume 35, pages 79 and 114f. Later references replace "BVerfGE" with "E". "RN" denotes a recital that provides the precise location of an argument on a page.
} 
Table 2 The three dimensions of the constitutional guarantee of freedom of science (emphasis by the authors)

\begin{tabular}{|c|c|}
\hline $\begin{array}{l}\text { Dimension/subject of the } \\
\text { freedom of Science }\end{array}$ & Constitutional texts \\
\hline $\begin{array}{l}\text { Person ("Everyone who } \\
\text { works scientifically", } \\
\text { special role of professors) }\end{array}$ & $\begin{array}{l}\text { "Arts and sciences, research and teaching shall be free. The freedom of } \\
\text { teaching shall not release any person from allegiance to the } \\
\text { constitution". (Federal Constitution Art. } 5 \text { III) }\end{array}$ \\
\hline $\begin{array}{l}\text { Organization (Universities, } \\
\text { Schools, Research } \\
\text { institutes) }\end{array}$ & $\begin{array}{l}\text { "Higher Education institutions shall be free in research and teaching". } \\
\text { (Constitution of Baden-Württemberg Art. 20) } \\
\text { "The basic rights shall also apply to domestic legal persons to the } \\
\text { extent that the nature of such rights permits". (Federal Constitution } \\
\text { Art. } 19 \text { III) }\end{array}$ \\
\hline $\begin{array}{l}\text { Functional system } \\
\text { research/science }\end{array}$ & $\begin{array}{l}\text { "Arts and sciences, research and teaching shall be free". (Federal } \\
\text { Constitution Art. } 5 \text { III) }\end{array}$ \\
\hline
\end{tabular}

derived from the personal-level understanding and not based on an understanding of the organisation as an actor that has a right to freedom of science itself.

The intermingling of personal and organisational interpretations of the freedom of research is expressed in rulings by the constitutional court according to which university professors must have the majority of votes on matters of university selfadministration that are relevant to science. ${ }^{5}$ However, the constitutional court also declared that the state must "provide for functioning institutions to undertake free academic work" (E 136, 338 RN 55, E 139, 148 RN 68), or that the individual freedom of science may be constrained in the interest of the "functional capability of higher education institutions" (E 126, 1 RN 55, our translation). Although the voluntary self-coordination of scientists within universities shall take precedence over heteronomous decisions by university management (E 126, 1 RN 56; for a discussion see Britz 2013: RN 91), the boundary between individual freedom and the organisation's functional capability remains open to interpretation, and the functional capability of organisations is independently protected.

The third dimension refers to the societal sub-system of science as an institutionalised system of action with specific functions (Britz 2013: RN 15, 68). This meaning has a textual reference in the wording of article five of the constitution, which declares "science" rather than the "scientist" to be free. According to the constitutional court, this fundamental right also protects "the functional capability of the institution of 'free science' as such" (BVerfGE 35, 79/120, our translation). This is

\footnotetext{
5 This is a position that Germany's Federal Constitutional Court has consistently upheld since its first ruling in 1973 (E35, 79-170).
} 
why it is regarded by some authors as a "functional fundamental right" ("Funktionsgrundrecht", Grimm 2007) in contrast to a personal right.

\section{Questions to be Addressed in Future Research}

Against this background of current discussions, several questions arise that merit further study in a comparative approach. These questions revolve around the abovementioned link between the normative legal structure and social reality. On the input side, the question arises how a pre-legal societal understanding of freedom of science is transferred into a formal legal structure. This is not trivial because the 'freedom of an informal institution' such as science also means freedom against its possibly too narrow formal definition by state institutions. A similar problem exists in fields such as arts or religion, where a critique against the "juridification of the religious" has already been expressed (Reuter 2014). On the output side an empirical study analysing how effective different systems of law are in protecting the freedom of science would be of interest. From the German experience and international comparison at least three overlapping approaches to the protection of the freedom of science can be distinguished, namely the constitutional protection of the freedom of science, the protection of the independence of higher education institutions, and the protection of freedom of speech (see above and Pritchard 1998; Karran 2007; Weingart 2014). Empirical analyses of the effects of these different legal arrangements can add to a deeper understanding of intended and unintended consequences of each of them, and would challenge assumptions of clarity and unambiguousness of the legal system.

This comparative approach needs to be combined with multi-level studies that address the personal, organisational and systemic level of legal protections for the freedom of science. In the German context, the current legal balancing of decision rights between universities' senior management and professors is of particular interest. Recent rulings invoke a balance between the rights of university professors to self-coordinate and the functional capability of higher education institutions without being able to draw on empirical evidence, which means that these rulings are based on empirically unfounded assumptions. The internationally comparative study of effects of legal arrangements on the individual researcher, the research organisation and the science system in society is thus both of theoretical interest and of political consequence.

\section{History of Higher Education and Science}

The independence of science, or academic freedom, has been addressed historically from multiple perspectives, three of which will be addressed here: the history of the idea and the legal practices of academic freedom; historical studies of science and scholarship in dictatorial regimes; and contemporary historical studies of the uses of scientific expertise in a variety of policy areas, including health issues and climate change. 
Histories of the Idea and Practices of Academic Freedom

The idea of freedom in science and scholarship is a long-standing topic in the history of universities. Discussion of the modern period is complicated by semantic issues that are themselves indicators of historically rooted differences in the situation of higher education and the sciences in different locations. The term 'academic freedom' is difficult to translate into other languages. Its common usage in English-and the absence of the term 'science' from the expression itself-are artefacts of historical circumstances in the United States, to be discussed below. In French, the commonly used terms are liberté des sciences or liberté des recherches; in German the word is Wissenschaftsfreiheit. Whether or not all of these terms are in fact equivalent is debatable.

An important example of this plural situation is the fact, rarely acknowledged in America-centric scholarship, that Wissenschaftsfreiheit is constitutionally guaranteed in German-speaking, but not in English-speaking countries (see above, Legal Studies). The relevant provision was first formulated in the abortive German constitution of 1849, and was incorporated into the constitutions of the North German Confederation and the Habsburg empire in 1867 (Müller 2008). Translated literally, the provision reads: "Research (Wissenschaft) and its teaching is free" (our translation and emphasis). This seemingly ungrammatical declaration suggests that the provision's authors (many of whom were themselves professors) considered academic teaching and research to be a unified activity. If we ask "freedom for whom?" in this case, what was formulated as a general constitutional right functioned primarily, though not entirely, a means of securing the power and status of the people in a position actually to exercise such rights, mainly full professors. Moreover, since professors in Germany were then and remain civil servants, their apparently guaranteed freedom could be limited or revoked when political regimes changed (see below).

In the United States, academic freedom has never been a basic constitutional right, but has been treated in the courts and in public debate as a special case of freedom of speech and opinion (Herbst 2008). The term itself came from the German Wissenschaftsfreiheit, and the principle still includes freedom of inquiry, but its meaning was modified in many other respects when it was adapted to the American context (Metzger 1978). Since universities in America can be either private or public institutions, tenure is guaranteed to faculty members by civil contract and other legal arrangements, but not by public law. Public opinion did not take kindly to any claim of special rights for academics in any case. The legal situation changed during the Cold War, when discrimination against leftist academics was prominent (Wang 2002). The Supreme Court declared for the first time in 1957 that academic freedom was protected by the US constitution (Herbst 2008: 325). Nonetheless, proponents of academic freedom in the US remain on the defensive, both against critiques from the left and from conservatives arguing that universities have become bastions of left-liberal conformity (Gross and Simmons 2014). 
Science in the Dictatorships of the Twentieth Century

Examples of ideologically corrupted science in dictatorships have often been cited to legitimize the superior value of science in democracies. Challenges to simple causal connections of this kind began already in the 1970s and 1980s; since then hundreds of studies of the sciences and scientific institutions under Nazism have appeared (for early overviews, see Walker and Renneberg 1994; Szöllösi-Janze 2001; for research at Kaiser Wilhelm Institutes see Heim et al. 2009; for analyses of Nazi-era science policy see Flachowsky 2008 and Nagel 2012). Work on the humanities has been part of this trend throughout (Hausmann 2002; Elvert and Nielsen-Sikora 2008; Bialas and Rabinbach 2007).

The current consensus among historians on this topic can be put briefly in four points:

(1) The dismissal of thousands of scholars and scientists of "non-Aryan" descent or left-wing political views that began in 1933 was not a direct attack on science and scholarship as such, but part of the Nazi effort to purge the German civil service, although some Nazis thought that this alone would suffice to "cleanse" German universities of liberal ideology (Grüttner 2005). The dismissals show that even constitutionally guaranteed freedoms could be revoked under certain political conditions. However, some universities and many disciplines were barely affected, because people of Jewish descent had not been present there in any case (Ash 2008).

(2) Initiatives to produce "ideologically correct" science such as "German Physics" came not from above, but from reactionary antisemitic scientists seeking to resolve internal battles, e.g. over relativity theory, by political means (Gordin et al. 2003).

(3) Contrary to older accounts claiming that Nazism was opposed by nature to modern science, research funding increased in the Nazi era, particularly in fields perceived to be most relevant to Nazism's policy goals: "racial hygiene" (Deichmann 1995; Proctor 1999; Weiss 2010), weapons research (Neufeld 1995; Heim et al. 2009, Section IV) and the forced resettlement of Slavic peoples to create "living space" for folkishly defined "Germans" in Eastern Europe (Heinemann and Wagner 2006; Fahlbusch and Haar 2010). Scientists willingly participated in such work; some scientists even helped to develop the policies being executed, or opportunistically represented existing research as relevant to current political priorities. Comparable results have emerged from more recent work on Mussolini's Italy and Franco's Spain (Gómez et al. 2015).

(4) Murderous human experiments in Nazi concentration camps and the appropriation of organs of victims of the killing of the physically or mentally handicapped for medical research (Kunz 2004) show how far the enablement of science by politics could go. Here, too, scientists were not forced to participate, but did so by choice. Human experimentation was by no means an aberration, but was rooted in attitudes and practices established before the Nazi era (Weindling 2017).

In contrast to Nazi Germany, the campaign to produce "ideologically correct science" under Communism came from above and peaked in the late 1940s, initiated by Politburo First Secretary Andrei Zhdanov in coordination with Stalin himself, who intervened at times to assure appropriate results, most notably in the case of 
Lyssenkoism. But such campaigns could not have succeeded without the participation of scientists, who saw institutional advantages in playing "games of Soviet democracy" (Krementsov 1997, chap. 6; Kojevnikov 2004, Chap. 8). And yet, the Soviet nuclear weapons program took place at the same time under the personal direction of Lavrenti Beria, head of the secret police (Holloway 1994; Kojevnikov 2004, Chap. 6); "ideologically correct" science served no purpose in this context. The simple fact that Stalinist science encompassed both Lyssenkoism and Pavlovism and first-class nuclear and rocket science and mathematics appears difficult for many to accept, even today.

The belief that dictatorships produce only poor-quality science or 'pseudoscience' is still widely held, but as these and other examples show, high quality science was supported by the dictatorships of the twentieth century, when it appeared to serve their interests (Walker 2012: 375).

That democracies, too, have chosen to limit academic freedom in certain circumstances is shown by policies enacted in the new German states established on the territory of the former East Germany following German unification. These states passed higher education 'renewal' laws that in essence required professors in East German universities to reapply for their former positions, based on a distinction between professors hired under the previous regime (Professoren nach bisherigem Recht) and under the new regime (Professoren nach neuem Recht) (Ash 1997: 98 ff.). These professors had to undergo political and moral assessments of their past behaviour by so-called 'honour' committees. Those who had served in higher party positions, had worked for the State Security Police or who had behaved in a manner deemed dishonourable could be and often were dismissed. In such cases the freedom of science and scholarship guaranteed by the German Basic Law was deliberately suspended in order to carry out a political purge of the teaching staff; newly appointed professors from the West were not subjected to such evaluations.

\section{Recent Historical Studies of Scientific Expertise}

In recent years, critical historical studies have appeared documenting recruitment of scientific expertise by large corporations to carry out studies intended to counteract the scientific basis of specific policies (see also above, Sociology). Well-known cases in point are studies of the relation of smoking and cancer (Proctor 2012), and research purporting to counter claims that climate change results from human activity, especially the use of fossil fuels (Conway and Oreskes 2010). In fact, the corporations involved understood that the government's and related research claims were sound, since their own earlier contract research had also shown this. Their purpose was not actually to refute public health or climate policy claims derived from established science, but to sow sufficient doubt about them to delay or prevent implementation of policies considered harmful to short-term corporate interests. Such tactics have increased pressure on publicly supported scientific bodies to engage in policy advocacy in their own right. Whether scientific independence is actually possible in such circumstances is an open question. 
Less well studied by historians of science are the reasons why such tactics succeed. To answer such questions it is necessary to go beyond science and consider the historically egalitarian civic culture of the US, reflected for example in the mainstream media's self-imposed requirement to report "both sides" of any debate, even when a consensus of informed scientific opinion supports only one "side". This convention is itself rooted in the widely shared belief that well-founded expert opinions should have equal standing with ordinary peoples' intuitive judgments, even if these turn out to be nothing more than self-interested wishes. The overrepresentation of scientific minority viewpoints due to such "balanced reporting" has been identified in the coverage of climate change by US media (Boykoff and Boykoff 2004), though it seems to be declining in this field. The norm of "balanced" reporting is not unique to US journalism, but persistent differences suggest that the way it is applied, and perhaps even the degree to which it is accepted, varies across countries (Brüggemann and Engesser 2017). ${ }^{6}$

From these varied historical perspectives it appears to be clear that both the claim that there is a necessary causal connection between the freedom of science, constitutionally guaranteed or not, and high-quality research results is as difficult to sustain as the claim that unfree regimes necessarily produce "pseudoscience". Relatively autonomous research has been possible in unfree societies, and in free societies research can be and is appropriated to serve political and economic interests.

Perhaps it is time to historicize the term "autonomy" itself, in particular to ask how claims to institutional "autonomy" have functioned as cultural codes for the establishment and maintenance of power relations within the research establishment. Reframing the question this way means asking not whether scientific independence has existed or not, but in what political circumstances what kinds of (limited) autonomy have been granted by whom for what reasons to whom, and above all what academic/scientific power holders have actually done with the (limited) autonomy granted to them. In this respect the history of science and higher education intersects with sociological approaches (Stichweh 2014, see also above, Sociology). A historical approach is distinguished from others by the insistence on situating cases of academic freedom, or unfreedom, in their specific times and places. In some cases at least, this can mean making an effort to historicize bad science on the same terms and with the same methods as epistemically robust science.

\section{Self-Reflections by Research Communities}

Scientific communities in the sciences, social sciences and humanities have reflected on two aspects of their dependence. First, there is a growing concern about the dependence of communities' epistemic judgments on incorrect information. Secondly, the dependence of researchers in the Global South on theories, approaches, and preferences of scholars in the Global North has come under scrutiny.

\footnotetext{
${ }^{6}$ We are indebted to Otfried Jarren, who introduced us to the literature on this subject.
} 
Beginning with the first concern, many fields in the sciences and social sciences have begun to reflect upon a loss of trust in published results. Problems include

- Errors in publications that spread through scientific communities (e.g. Vaughan et al. 2017)

- Results that cannot be reproduced for a variety of (partly unknown) reasons (Ioannidis 2005; Baker 2016),

- Interpretation bias or "spin", which is defined as "reporting practices that distort the interpretation of results and mislead readers so that results are viewed in a more favourable light" (Chiu et al. 2017: 11; Lieb et al. 2016; Stoll et al. 2020).

- Fraud, i.e. the falsification of results (Hesselmann et al. 2017; Byrne 2019).

These phenomena directly bear on the independence of research because they are caused by individual producers losing their independence and because they threaten the independence of scientific communities. Causes of the perceived upsurge of publications that cannot be trusted can be conceptualised as conflicts of interest (COI). These COIs have been most extensively discussed in medicine, which has a long tradition of reflecting upon independence due to both the nature of physicians' professional practice-where the norm of independence can be traced back to the Hippocratic Oath - and the long-standing issue of influences on medical research exercised by industry.

Medical researchers define COI as "a set of circumstances that are reasonably believed to create a substantial risk that professional judgment of a primary interest will be unduly influenced by a secondary interest" (Thompson 2009: 137). In this approach, the independence of a researcher is conceptualised as the opportunity to realise the primary interest of extending reliable knowledge for the patients' benefit. This primary interest can be impeded by secondary interests such as personal gains like money or prestige, the interest to comply with external pressure, or the interest in seeing one's preconceptions confirmed. Three kinds of COI have been discussed in medicine and other fields of the sciences and social sciences:

- A researcher's independence and thus their realisation of primary interests can be endangered by external pressures, e.g. by demands from or contractual obligations to pharmaceutical companies, by the pressure to publish or to meet demands from employers. These conflicts of interest have also been investigated by the sociology of science and economics (see 2.1 and 2.2). They may lead to the suppression (non-publication) of findings that contradict interests of clients or publications that are biased towards clients' interests (publication bias).

- Researchers may consciously sacrifice their primary interest in order to advance their status, career, or income. This practice is the focus of a wide-ranging discussion on fraud and questionable research practices like "HARKing" (hypothesising after results are known, Kerr 1998) and "p-hacking" (the selection or transformation of data in order to produce statistically significant results, Head et al. 2015).

- Researcher independence may also be constrained if researcher allegiance, which is understood as the adherence of a researcher to a theory or approach, turns into 
epistemic prejudice that overrides the primary interest. Researcher allegiance, which so far has been studied most extensively in psychotherapy outcome research (Munder et al. 2013), is a ubiquitous phenomenon because all researchers have an allegiance to the theories and approaches that form their scientific perspective. However, allegiance may turn into a strong interest in confirming the superiority of theories or approaches regardless of the available evidence. This interest may lead to prejudice without any external influence (Lieb et al. 2016). ${ }^{7}$

Framing conscious and subconscious violations of primary interests as a loss of independence adds a new perspective to the discussion of the independence of research by addressing conflicts between different interests of the same researcher. ${ }^{8}$ While most discussions of the topic consider the independence from other actors, our definition of independence as "the extent to which an actor in science is free from influences that alter its choices" (see above) enables a wider perspective. Our historical account already points to the use of independence for serving one's own interests or the interests of a regime. The interpretation of a COI as the risk of secondary interests unduly influencing professional judgement aligns with this discussion. Our main reason for including these perspectives is that a researcher facing a conflict of interests is the primary mechanism through which all losses of independence are translated into changes in research content. Researchers are "obligatory points of passage" (Callon 1986: 205-206) for most influences on research content (Gläser 2019: 421-423). Limiting the independence of researchers leads to COIs, and the discussion of allegiance-turned-prejudice just adds a version of this translation mechanism.

Including these versions of COIs in our consideration of the independence of research links the interests of scientific communities in preventing COIs to the study of independence by the fields reviewed in the preceding sections. The treatment of questionable research practices by the sociology of science, of academy-industry collaboration by economics and the sociology of science, of research under unfree regimes by the history of science and of objectivity by the philosophy of science all intersect with considerations of the 'internal independence' of researchers.

The most important consequence of COIs is the proliferation of unreliable publications, which is currently discussed by several scientific communities in the sciences and social sciences. The experience that published results cannot be trusted may accumulate and erode the implicit trust in colleagues' findings, which is one of the foundations of the communal production of scientific knowledge. Building research on findings that later turn out to be incorrect may slow down or misdirect a community's knowledge production, both of which waste scarce resources (Byrne 2019).

To prevent these possible distortions of their knowledge production, some scientific communities have increased their scrutiny of researchers and begun to introduce

\footnotetext{
7 A similar argument has been made for the allegiance to religious beliefs (Smith and Blazeby 2018).

${ }^{8}$ We are grateful to the reviewer who pointed this out and forced us to make our reasoning explicit.
} 
regulations that prevent unreliable publications. A by now well-established rule prescribes the declaration of COIs (Fontanarosa and Bauchner 2017). More recently, the pre-registration of studies and the publication of registered reports have been introduced in order to prevent the retrospective adjustment of study designs (Zarin and Tse 2008; van 't Veer and Giner-Sorolla 2016). The pre-registration of studies is sometimes criticised as lessening the independence of researchers and reducing the flexibility of research (ibid.).

A second major concern of an increasing number of scientific communities is the dependence of scholars in the Global South from those in the Global North. In the sciences, this dependence is discussed mainly in terms of unequal power in research collaborations (e.g. Binka 2005). Discussions in the social sciences and humanities focus on the role of the Global North as the sole source of dominant theories and approaches (Connell 2006; Keim 2011; Acharya and Buzan 2017) and on the mechanisms that reproduce the Northern dominance in these communities (Tickner and Wæver 2009; Keim 2011; Landau 2012; Maliniak et al. 2018; Kreimer 2019: 3). The elaboration of mechanisms (curricula worldwide dominated by Northern theories and approaches, $\mathrm{PhD}$ programmes of the Global North dominating postgraduate education, leading journals being dominated by scholars from the Global North and so on) makes a convincing case that the emergence of theories in the Global South and their diffusion are more than difficult under current conditions. In any case, the communities in question (our examples refer to sociology and international relations) are still in the process of taking stock. First actions taken include attempts by leading international relations journals to prevent bias in the selection of manuscripts for publication.

\section{Interdisciplinary Prospects}

In this section, we demonstrate that an integration of disciplinary approaches to studying the independence of research can be achieved by developing two perspectives. The first perspective treats the independence of research as a dependent variable by focusing on the social construction of independence in constellations of interdependent actors. The second perspective targets the effects of varying degrees of independence by exploring the links between varying levels and forms of independence and the content of research. These two perspectives enable the formulation of research questions that meet the interests and require the collaboration of the disciplines reviewed in the preceding sections.

\section{The Social Construction of Independence}

This perspective considers independence as the historically and situationally contingent outcome of negotiations between actors. An important part of these negotiations is that specific forms of independence are granted to particular individuals, groups and organisations by actors who have the authority to do so. The history of science emphasizes that which independence is granted to whom depends on 
specific historical situations. Neither are all researchers or research organisations in a country equally independent at any time, nor is independence in any way constant-not least because the understanding of independence itself is constantly changing. Legal studies discuss formal institutions through which the state grants researchers and research organisations independence. These institutions are not static because the legal allocation of rights to independence must constantly balance the rights to independence of a variety of actors in the science system against each other and with rights of other societal actors, while taking into account the interest of the state and other actors in influencing research. Higher education research and research on academic careers address the dynamics of these relationships in their research on the evolution of higher education governance and on changes in academic careers, which typically but not always include a move from dependent to independent research.

Several disciplinary perspectives emphasize that an actor's actual independence is not just granted but is also the outcome of negotiation processes, which take place in specific historical circumstances and involve actors with varying authority and interests. This is why a researcher's actual independence may deviate from the independence they are formally granted by legislation and other rules. Researchers in positions of formal independence may in fact conduct dependent research and vice versa. Formal rights to independence may set limits to the variation of actual independence and serve as a resource in negotiations of independence. They do not, however, determine it.

An important process in many contexts in which independence is negotiated is the peer review of researchers, projects, publications, or of research organisations. Peer review impacts directly or indirectly on the independence of researchers or research organisations by expressing whether some research meets standards of quality and relevance. While being most prominent in the discussion of researcher autonomy in the sociological perspective, it also plays an important role in the competitions discussed by economics, in the handling of conflicts of interests and in the discovery of bias by research communities, and in the discussion of pluralism by the philosophy of science. While the impact of peer review on research has enjoyed some attention, its role in the negotiation of researcher independence has rarely been explicitly discussed (for an exception see Shibayama and Baba 2015 on "dishonest conformity" in peer review). Considering it as a process that both limits researcher independence and curbs the abuse of that independence will contribute to a better understanding of its functions and limits.

The intentional influences of granting and negotiating independence are complemented by unintended consequences for the independence of research, i.e. by influences on the independence of research that are a by-product of actions with different purposes. A common focus of several disciplinary approaches are the unintended consequences of competition in science. The competition of researchers and research organisations for recognition and resources is a long-standing topic of both economics and sociology. This competition indirectly affects the independence of participants by modifying their mutual dependence and increasing inequalities between them. These effects of competition on the independence of participants are not yet well understood. They may include a felt pressure to conform to a field's 
mainstream or to engage in collaborations, to avoid risks, or the felt need to utilise one's independence for engaging in questionable research practices or even fraud.

Competition might also limit the independence of those who are forced to participate while being far less equipped for them than their competitors. It is trivially true that there is no level playing field in international scientific communities. An increasing number of scientific communities notice that the global competition for recognition they engage in systematically disadvantages researchers in the Global South, while domestic competitive structures disadvantage women and may disadvantage young researchers. This growing self-awareness of scientific communities opens avenues for productive collaborations between science studies scholars and scientific communities.

Two questions for interdisciplinary research can be derived from these intersections of disciplinary interests. First, we should ask how actors in the science system negotiate their actual independence under historically and nationally specific circumstances. Second, we should ask how historically changing understandings of the independence of research affect the differential granting of formal independence to actors in the science system.

\section{The Relationship Between Independence and the Content of Research}

A second interest that is common to all approaches we reviewed in this paper concerns the impact of different levels and forms of independence on the content of research. The independence of research has been linked to its quality, to changes in its directions, to its novelty or innovativeness, and to its adherence to methodological and ethical standards. Concerning quality, the history of science teaches us that high-quality research is also possible in societies that don't grant their researchers much overall independence. A high degree of independence of research in a country does not appear to be a necessary condition for excellent research. This is confirmed by studies in the sociology of science and economics that did not find research conducted in academy-industry collaborations to be of lower quality. More generally, there are no reasons to assume that more independence is always 'better' in the sense that it guarantees faster progress or more solutions to societal problems, as findings from the history and philosophy of science indicate.

The link between constraints on the independence of research and changes in its direction is the common concern of several disciplines. Empirical research in the sociology of science and economics as well as reflections by scientific communities on conflicts of interest have demonstrated that the dependence of research on interest-driven funding or on particular funding arrangements may lead to changes in the directions of research. Among these, the adaptation of research content to expectations of funders (mainly industry) has been researched most extensively by the sociology of science, economics, and the history of science. Sociological studies also point to possible effects of funding formats such as the duration of funding or budgetary structures, which may enable only some of a field's research processes and thus supress others. Finally, economics and the sociology of science alert us to the possibility of a general homogenising effect of competitions. 
Several disciplines share an interest in the ambivalent relationship between the independence of researchers and the adherence of their epistemic judgments to community standards. Researchers might lose the independence of their epistemic judgment by subconsciously warping research designs, results, or interpretations of results according to secondary interests such as financial gains or strengthening scientific positions they adhere to. However, they may also exploit the social independence they negotiated for themselves by intentionally violating methodological or ethical standards. The sociology of science and discussions in scientific communities point to fraud and questionable research practices, and recent discussions in the history and philosophy of science have raised the issue of "manufactured dissent", i.e. the creation of scientific positions that support specific societal interests rather than advancing the community's knowledge.

Both the loss of independence of epistemic judgements and the abuse of independence for the intentional violation of epistemic standards may affect collective epistemic judgments of scientific communities. The relationship between individual and community-level epistemic judgments is a theme running through all approaches to the independence of research because all investigations of the independence of research face the question whether individual-level variations of independence and their consequences for research are just 'noise' that does not affect the knowledge production of scientific communities. Since collective epistemic judgments of scientific communities depend on individual contributions, any impact of researcher independence on epistemic judgements may affect collective-level epistemic judgments.

The reverse is of course true as well. Since scientific communities influence the allocation of positions and of resources for research as well as the recognition of results through peer reviews, researchers are dependent on preferences and standards of their communities. Current discussions in scientific communities indicate that researchers in the Global South might not be able to exercise independent epistemic judgment or gain recognition for their contributions because community standards and preferences are those of the Global North. Members of scientific communities in the Global North control a significant proportion of the research funding for the Global South, which gives them the opportunity to implement their priorities and standards. This can occur either intentionally or unintentionally. Since all central publication channels of scientific communities are also controlled by researchers from the global North, contributions from the Global South that don't meet interests of Northern elites are unlikely to enter these communication channels. Thus, scientific communities can impose their majority opinion on researchers through a variety of channels.

Disciplinary approaches to the impact of the independence of research on its content can be integrated with a focus on three questions. First, a common focus of all disciplines whose approaches to the independence of research we discussed in this paper and of a growing number of scientific communities is expressed by the following question: Under what circumstances, by what mechanisms and with what effects do changes in the independence of individual researchers lead to changes of research content at the individual and community levels? Second, there is the question of how the epistemic (in) dependence of researchers from standards and majority opinions of their community is maintained. Third, this leads to the question about the 
conditions under which this dependence may change the content of research at the individual or community level.

Investigating conditions for and effects of individual and collective epistemic prejudice also poses two major methodological challenges. The first challenge is measuring prejudice at all. It is the nature of prejudices in general, and epistemic prejudices in particular that they are not recognized as such by those who believe in them. Researchers are not aware of their epistemic prejudices and let them influence their actions without noticing. Dana and Loewenstein (2003) and Moore and Loewenstein (2004) summarise research according to which bias is more frequently the result of motivational processes that are unintentional and unconscious. This challenge to measuring prejudice might be overcome by drawing on sociological methods of frame analysis and psychological research on implicit bias. In close connection with the problem of identifying prejudice, the identification of its effects, i.e. of spin and other biases in publications, is a challenge that requires the collaboration of the social sciences with the investigated scientific communities because only they can assess the content of their publications.

\section{Conclusions}

From this review of disciplinary perspectives on conditions and effects of the independence of research and the identification of topics on which disciplinary perspectives converge four conclusions can be drawn. First, the independence of researchers, research organisations and scientific communities is an important intermediary for influences on research content. It constitutes an "obligatory point of passage" (Callon 1986: 205-206) for influences on the content of research.

Secondly, the disciplinary perspectives share the methodological challenge of empirically determining the independence of actors in science and its epistemic effects. The idea of 'measuring' an actor's (in) dependence from other actors in the science system, the (in)dependence of an actor's or a scientific community's epistemic judgements, or the effects of this independence on the research content is not yet well supported by methodologies of the disciplines engaging with the problem.

Thirdly, the independence of research has nevertheless proven its usefulness as a "boundary object" (Star and Griesemer 1989) for the collaboration of disciplines engaged with the subject. We demonstrated how the abstract concept of (in)dependence is specified for the purposes of different disciplines, and how it can support the collaboration of disciplines that all contribute important partial insights in the conditions and effects of the independence of research.

Finally, the value of our topic extends beyond the usual collaboration of disciplines in that it also supports the prospects of scholars studying the independence of research collaborating with scientific communities experiencing threats to the independence of their research. Both partners can benefit from this collaboration. Scientific communities concerned about threats to the independence of their research can utilise systematic research on these threats, their effects, and effects of communities' 
responses to perceived threats. Research would also support reflections by actors on the ways in which their actions may constrain independence, and on ways the independence of research may be abused. Researchers studying independence can in turn benefit from support for their investigation of epistemic consequences of the (in) dependence of research.

Funding Research for this paper was supported by the Volkswagen Foundation (Grant 91498). Open Access funding enabled and organized by Projekt DEAL.

Open Access This article is licensed under a Creative Commons Attribution 4.0 International License, which permits use, sharing, adaptation, distribution and reproduction in any medium or format, as long as you give appropriate credit to the original author(s) and the source, provide a link to the Creative Commons licence, and indicate if changes were made. The images or other third party material in this article are included in the article's Creative Commons licence, unless indicated otherwise in a credit line to the material. If material is not included in the article's Creative Commons licence and your intended use is not permitted by statutory regulation or exceeds the permitted use, you will need to obtain permission directly from the copyright holder. To view a copy of this licence, visit http://creativecommons.org/licen ses/by/4.0/.

\section{References}

Acharya, A., and B. Buzan. 2017. Why is there no Non-Western International Relations Theory? Ten years on. International Relations of the Asia-Pacific. https://doi.org/10.1093/irap/lcx006.

Ash, M.G. 1997. Higher Education and German Unification: "Renewal" or the Importation of Crisis? In German Universities Past and Future: Crisis or Renewal?, ed. Mitchell G. Ash, 84-109. Oxford, England and Providence, RI: Berghahn Books.

Ash, Mitchell G. 2008. Forced Migration and Scientific Change: Steps Towards A New Approach. In The Migration of Ideas, eds. Roberto Scazzieri and Raffaela Simili, 161-178. Sagamore Beach, MA: Science History Publications.

Azoulay, Pierre, Waverly Ding, and Toby Stuart. 2009. The Impact of Academic Patenting on the Rate, Quality and Direction of (Public) Research Output. The Journal of Industrial Economics 57: 637-676.

Baker, Monya. 2016. 1,500 scientists lift the lid on reproducibility. Nature. https://doi.org/10.1038/53345 $2 \mathrm{a}$.

Barnett, Allain J., and Melanie G. Wiber. 2018. What Scientists Say About the Changing Risk Calculation in the Marine Environment Under the Harper Government of Canada (2006-2015). Science, Technology, \& Human Values. https://doi.org/10.1177/0162243918781269.

Barr, Nicholas. 1998. The Economics of the Welfare State. London: Weidenfeld and Nicholson.

Bekelman, J.E., Y. Li, and C.P. Gross. 2003. Scope and impact of financial conflicts of interest in biomedical research: a systematic review. JAMA. https://doi.org/10.1001/jama.289.4.454.

Bialas, Wolfgang, and Anson Rabinbach, (eds.). 2007. Nazi Germany and the Humanities. Oxford: Oneworld.

Biddle, Justin, and Eric Winsberg. 2010. Value Judgements and the Estimation of Uncertainty in Climate Modeling. In New Waves in Philosophy of Science, eds. P. D. Magnus and Jacob Busch, 172-197. London: Palgrave Macmillan.

Biddle, Justin B., and Anna Leuschner. 2015. Climate skepticism and the manufacture of doubt: can dissent in science be epistemically detrimental? European Journal for Philosophy of Science. https:// doi.org/10.1007/s13194-014-0101-x.

Binka, Fred. 2005. Editorial: North-South research collaborations: a move towards a true partnership? Tropical Medicine \& International Health. https://doi.org/10.1111/j.1365-3156.2004.01373.x.

Blumenthal, David, Eric G. Campbell, Melissa S. Anderson, Nancyanne Causino, and Karen Seashore Louis. 1997. Withholding research results in academic life science-Evidence from a national survey of faculty. JAMA. https://doi.org/10.1001/jama.1997.03540390054035. 
Bourdieu, Pierre. 1975. The specifity of the scientific field and the social conditions of the progress of reason. Social Science Information 14: 19-47.

Boykoff, Maxwell T., and Jules M. Boykoff. 2004. Balance as bias: global warming and the US prestige press. Global Environmental Change. https://doi.org/10.1016/j.gloenvcha.2003.10.001.

Braun, Dietmar. 1998. The role of funding agencies in the cognitive development of science. Research Policy. https://doi.org/10.1016/S0048-7333(98)00092-4.

Britz, Gabriele. 2013. Kommentierung von Art. 5 III (Wissenschaft). In Grundgesetz-Kommentar Bd. 1., ed. Horst Dreier, 792-838. Tübingen: Mohr Siebeck, 3rd edition.

Brown, Phil, Sabrina McCormick, Brian Mayer, Stephen Zavestoski, Rachel Morello-Frosch, Rebecca Gasior Altman, and Laura Senier. 2006. "A Lab of Our Own": Environmental causation of breast cancer and challenges to the dominant epidemiological paradigm. Science, Technology \& Human Values. https://doi.org/10.1177/0162243906289610.

Brüggemann, Michael, and Sven Engesser. 2017. Beyond false balance: How interpretive journalism shapes media coverage of climate change. Global Environmental Change. https://doi.org/10.1016/j. gloenvcha.2016.11.004.

Byrne, Jennifer. 2019. We need to talk about systematic fraud. Nature. https://doi.org/10.1038/ d41586-019-00439-9.

Callon, Michel. 1986. Some Elements of a Sociology of Translation: Domestication of the Scallops and the Fishermen of St Brieuc Bay. In Power, Action and Belief, ed. John Law, 196-233. London: Routledge.

Capano, Gilberto. 2011. Government Continues to do its Job. A comparative study of governance shifts in the higher education sector. Public Administration. https://doi.org/10.1111/j.1467-9299.2011. 01936.x.

Chiu, Kellia, Quinn Grundy, and Lisa Bero. 2017. 'Spin' in published biomedical literature: A methodological systematic review. PLOS Biology. https://doi.org/10.1371/journal.pbio.2002173.

Chubin, Daryl E., and Edward J. Hackett. 1990. Peerless Science: Peer Review and U.S. Science Policy. Albany, NY: State University of New York Press.

Ciarli, Tommaso, and Ismael Ràfols. 2019. The relation between research priorities and societal demands: The Case of Rice. Research Policy. https://doi.org/10.1016/j.respol.2018.10.027.

Connell, Raewyn. 2006. Northern theory: The political geography of general social theory. Theory and Society. https://doi.org/10.1007/s11186-006-9004-y.

Czarnitzki, Dirk, Christoph Grimpe, and Maikel Pellens. 2015. Access to research inputs: open science versus the entrepreneurial university. The Journal of Technology Transfer. https://doi.org/10.1007/ s10961-015-9392-0.

Dana, Jason, and George Loewenstein. 2003. A social science perspective on gifts to physicians from industry. JAMA. https://doi.org/10.1001/jama.290.2.252.

Dasgupta, Partha, and Paul A. David. 1994. Toward a new economics of science. Research Policy. https:// doi.org/10.1016/0048-7333(94)01002-1.

David, Paul A. 1998a. Clio and the Economic Organization of Science: Common Agency Contracting and the Emergence of "Open Science" Institutions. AEA Papers and Proceedings (May): 15-21.

David, Paul A. 1998b. Communication norms and the collective cognitive performance of "invisible colleges". In Creation and Transfer of Knowledge. Institutions and Incentives, eds. G. Barba Navaretti, P. Dasgupta, K.-G. Mäler and D. Siniscalco, 115-163. Berlin: Springer.

Deichmann, Ute. 1995. Biologists under Hitler, trans. Th. Dunlap. Cambridge, MA: Harvard University Press.

de Melo-Martin, Inmaculada, and Kristen Intemann. 2018. The fight against doubt: how to bridge the gap between scientists and the public. Oxford: Oxford University Press.

Dill, David, Pedro Teixeira, Ben Jongbloed, and Alberto Amaral. 2004. Conclusion. In Markets in Higher Education: Rhetoric or Reality, eds. Pedro Teixeira, Ben Jongbloed, David Dill, and Alberto Amaral, 327-352. Dordrecht: Kluwer.

Doucouliagos, Hristos, and T.D. Stanley. 2009. Publication Selection Bias in Minimum-Wage Research? A Meta-Regression Analysis. British Journal of Industrial Relations. https://doi.org/10.1111/j. 1467-8543.2009.00723.x.

Douglas, Heather. 2000. Inductive Risk and Values in Science. Philosophy of Science. https://doi.org/10. $1086 / 392855$

Douglas, Heather E. 2009. Science, Policy, and the Value-Free Ideal. Pittsburgh: University of Pittsburgh Press. 
Elliott, Kevin C. 2011. Is a Little Pollution Good for You? Incorporating Societal Values in Environmental Research. Oxford: Oxford University Press.

Elvert, Jürgen, and Jürgen Nielsen-Sikora, (eds.). 2008. Kulturwissenschaften und Nationalsozialismus. Stuttgart: Franz Steiner Verlag.

Enders, Jürgen, Harry de Boer, and Elke Weyer. 2013. Regulatory autonomy and performance: the reform of higher education re-visited. Higher Education. https://doi.org/10.1007/s10734-012-9578-4.

Enyedi, Zsolt. 2018. Democratic Backsliding and Academic Freedom in Hungary. Perspectives on Politics. https://doi.org/10.1017/S1537592718002165.

Etzkowitz, Henry. 2003. Research groups as 'quasi-firms': the invention of the entrepreneurial university. Research Policy. https://doi.org/10.1016/S0048-7333(02)00009-4.

Evans, James A. 2010a. Industry collaboration, scientific sharing, and the dissemination of knowledge. Social Studies of Science. https://doi.org/10.1177/0306312710379931.

Evans, James A. 2010b. Industry Induces Academic Science to Know Less about More. American Journal of Sociology. https://doi.org/10.1086/653834.

Fahlbusch, Michael, and Ingo Haar, (eds.). 2010. Völkische Wissenschaften und Politikberatung im 20. Jahrhundert. Paderborn: Schöningh.

Flachowsky, Sören. 2008. Von der Notgemeinschaft zum Reichsforschungsrat. Wissenschaftspolitik im Kontext von Autarkie. Aufrüstung und Krieg: Franz Steiner Verlag, Stuttgart.

Fontanarosa, Phil, and Howard Bauchner. 2017. Conflict of Interest and Medical Journals. JAMA. https:// doi.org/10.1001/jama.2017.4563.

Frickel, Scott, and Neil Gross. 2005. A General Theory of Scientific/Intellectual Movements. American Sociological Review. https://doi.org/10.1177/000312240507000202.

Frickel, Scott, Sahra Gibbon, Jeff Howard, Joanna Kempner, Gwen Ottinger, and David J. Hess. 2010. Undone Science: Charting Social Movement and Civil Society Challenges to Research Agenda Setting. Science, Technology \& Human Values. https://doi.org/10.1177/0162243909345836.

Frisch, Mathias. 2013. Modeling Climate Policies: A Critical Look at Integrated Assessment Models. Philosophy and Technology. https://doi.org/10.1007/s13347-013-0099-6.

Gaillard, Jacques F. 1994. North-South research partnership: Is collaboration possible between unequal partners? Knowledge and Policy 7: 31-63.

Gläser, Jochen. 2019. How can governance change research content? Linking science policy studies to the sociology of science. In Handbook on Science and Public Policy, eds. Dagmar Simon, Stefan Kuhlmann, Julia Stamm, and Weert Canzler, 419-447. Cheltenham: Edward Elgar.

Gläser, Jochen, and Grit Laudel. 2016. Governing Science: How Science Policy Shapes Research Content. European Journal of Sociology / Archives Européennes De Sociologie. https://doi.org/10. 1017/S0003975616000047.

Gläser, Jochen, and Uwe Schimank. 2014. Autonomie als Resistenz gegen Beeinflussung. Forschungshandeln im organisatorischen und politischen Kontext. In Autonomie revisited. Beiträge zu einem umstrittenen Grundbegriff in Wissenschaft, Kunst und Politik. Zeitschrift für Theoretische Soziologie, 2. Sonderband, eds. Martina Franzen, Arlena Jung, David Kaldewey and Jasper Korte, 41-61. Weinheim: Beltz Juventa.

Goldman, Gretchen T., Emily Berman, Michael Halpern, Charise Johnson, Yogin Kothari, Genna Reed, and Andrew A. Rosenberg. 2017. Ensuring Scientific Integrity in the Age of Trump. Science. https://doi.org/10.1126/science.aam5733.

Gómez, Amparo, Antonio FCO. Canales, and Brian Balmer (eds.). 2015. Science Policies and TwentiethCentury Dictatorships: Spain, Italy and Argentina. Franham/Burlington: Ashgate.

Gordin, Michael, Walter Grunden, Mark Walker, and Zuoyue Wang. 2003. "Ideologically Correct" Science. In Science and Ideology: A Comparative History, ed. Mark Walker, 35-65. New York: Routledge.

Grimm, Dieter. 2007. Wissenschaftsfreiheit vor neuen Grenzen? Göttingen: Wallstein.

Gross, Neil, and Solon Simmons (eds.). 2014. Professors and their Politics. Baltimore: Johns Hopkins University Press.

Grüttner, Michael. 2005. German Universities under the Swastika. In Universities under Dictatorship, eds. John Connelly and Michael Grüttner, 75-112. University Park: Pennsylvania State University Press.

Gusterson, Hugh. 1995. Becoming a Weapons Scientist. In Technoscientific Imaginaries-Conversations, Profiles, and Memoirs, ed. George E. Marcus, 255-273. Chicago: University of Chicago Press. 
Gusterson, Hugh. 2003. The Death of the Authors of Death: Prestige and Creativity among Nuclear Weapons Scientists. In Scientific Authorship: Credit and Intellectual Property in Science, eds. Mario Biagioli and Peter Galison, 281-307. New York and London: Routledge.

Hagstrom, Warren O. 1982. Gift giving as an organizing principle in science. In Science in Context, eds. Barry Barnes and David Edge, 21-34. Readings in the Sociology of Science: The Open University Press, Milton Keynes.

Hausmann, Frank-Rutger. 2002. Die Rolle der Geisteswissenschaften im Dritten Reich 1933-1945. München: Oldenbourg.

Head, Meagan L., Luke Holman, Rob Lanfear, Andrew T. Kahn, and Michael D. Jennions. 2015. The Extent and Consequences of P-Hacking in Science. PLOS Biology. https://doi.org/10.1371/journ al.pbio. 1002106 .

Heim, Susanne, Carola Sachse, and Mark Walker (eds.). 2009. The Kaiser Wilhelm Society under National Socialism. Cambridge: Cambridge University Press.

Heinemann, Isabel, and Patrick Wagner (eds.). 2006. Wissenschaft_Planung-Vertreibung. Neuordnungskonzepte und Umsiedlungspolitik im 20. Jahrhundert. Stuttgart: Franz Steiner Verlag.

Heinze, Thomas. 2008. How to Sponsor Ground-Breaking Research: A Comparison of Funding Schemes. Science and Public Policy. https://doi.org/10.3152/030234208X317151.

Hell, Stefan. 2019. "Greift nach den Sternen ..." Ein Interview mit einem Nobelpreisträger. Forschung \& Lehre 11/ 2019. https://www.forschung-und-lehre.de/karriere/greift-nach-den-sternen-2272/. Accessed 2 June 2021.

Herbst, Jürgen. 2008. Akademische Freiheit in den USA. Privileg der Professoren oder Bürgerrecht? In Wissenschaftsfreiheit in Vergangenheit und Gegenwart, eds. Rainer Albert Müller and Rainer C. Schwinges, 317-330. Basel: Schwabe Verlag.

Hesselmann, Felicitas, Verena Graf, Marion Schmidt, and Martin Reinhart. 2017. The visibility of scientific misconduct: A review of the literature on retracted journal articles. Current Sociology. https:// doi.org/10.1177/0011392116663807.

Hillman, Arye L., and Dov Samet. 1987. Dissipation of contestable rents by small numbers of contenders. Public Choice 54: 63-82.

Holloway, David. 1994. Stalin and the Bomb: The Soviet Union and Atomic Energy 1936-1956. New Haven: Yale University Press.

Holman, Bennett, and Justin P. Bruner. 2015. The Problem of Intransigently Biased Agents. Philosophy of Science. https://doi.org/10.1086/683344.

Hottenrott, Hanna, and Susanne Thorwarth. 2011. Industry Funding of University Research and Scientific Productivity. Kyklos. https://doi.org/10.1111/j.1467-6435.2011.00519.x.

Ioannidis, John P. A. 2005. Why Most Published Research Findings Are False. PLOS Medicine. https:// doi.org/10.1371/journal.pmed.0020124.

Karran, Terence. 2007. Academic Freedom in Europe: A Preliminary Comparative Analysis. Higher Education Policy. https://doi.org/10.1057/palgrave.hep.8300159.

Keim, Wiebke. 2011. Counterhegemonic currents and internationalization of sociology: Theoretical reflections and an empirical example. International Sociology. https://doi.org/10.1177/0268580909 351324.

Kern, Scott E. 2012. Why Your New Cancer Biomarker May Never Work: Recurrent Patterns and Remarkable Diversity in Biomarker Failures. Cancer Research. https://doi.org/10.1158/0008-5472. CAN-12-3232.

Kerr, Norbert L. 1998. HARKing: Hypothesizing After the Results are Known. Personality and Social Psychology Review. https://doi.org/10.1207/s15327957pspr0203_4.

Kitcher, Philip. 1990. The Division of Cognitive Labor. The Journal of Philosophy 87: 5-22.

Kitcher, Philip. 2001. Science, Truth, and Democracy. Oxford: Oxford University Press.

Kitcher, Philip. 2011. Science in a Democratic Society. New York: Prometheus Books.

Kojevnikov, Alexei B. 2004. Stalin's Great Science: The Times and Adventures of Soviet Physicists. London: Imperial College Press.

Kourany, Janet A. 2010. Philosophy of Science after Feminism. Oxford: Oxford University Press.

Kreimer, Pablo. 2019. Are we eating the cannibal? Reflections on Latin American STS facing provincializing STS. Science, Technology \& Society 24: 2-3.

Krementsov, Nikolai. 1997. Stalinist Science. Princeton: Princeton University Press.

Krimsky, Sheldon. 2013. Do Financial Conflicts of Interest Bias Research?: An Inquiry into the "Funding Effect" Hypothesis. Science, Technology \& Human Values. https://doi.org/10.1177/0162243912 456271 . 
Krücken, Georg. 2019. Multiple competitions in higher education: a conceptual approach. Innovation. https://doi.org/10.1080/14479338.2019.1684652.

Kuhn, Thomas. 1962. The Structure of Scientific Revolutions. Chicago: The University of Chicago Press.

Kummerfeld, Erich, and Kevin J. S. Zollman. 2016. Conservatism and the Scientific State of Nature. The British Journal for the Philosophy of Science. https://doi.org/10.1093/bjps/axv013.

Kunz, Dieter, and Susan Bachrach (eds.). 2004. Deadly Medicine: Creating the Master Race. Chapel Hill: University of North Carolina Press.

Landau, Loren B. 2012. Communities of Knowledge or Tyrannies of Partnership: Reflections on NorthSouth Research Networks and the Dual Imperative. Journal of Refugee Studies. https://doi.org/10. $1093 / \mathrm{jrs} / \mathrm{fes} 005$.

Latour, Bruno, and Steve Woolgar. 1982. The cycle of credibility. In Science in Context Readings in the Sociology of Science, eds. Barry Barnes and David Edge, 35-43. Milton Keynes: The Open University Press.

Lave, Rebecca, Philip Mirowski, and Samuel Randalls. 2010. Introduction: STS and Neoliberal Science. Social Studies of Science. https://doi.org/10.1177/0306312710378549.

Le Grand, Julian, and Will Bartlett (eds.). 1993. Quasi-Markets and Social Policy. Houndmills: Macmillan Press.

Lieb, Klaus, Jan von der Osten-Sacken, Jutta Stoffers-Winterling, Neele Reiss, and Jürgen Barth. 2016. Conflicts of interest and spin in reviews of psychological therapies: a systematic review. British Medical Journal Open. https://doi.org/10.1136/bmjopen-2015-010606.

Longino, Helen. 1990. Science as Social Knowledge: Values and Objectivity in Scientific Inquiry. Princeton: Princeton University Press.

Longino, Helen E. 1996. Cognitive and Non-Cognitive Values in Science: Rethinking the Dichotomy. In Feminism, Science, and the Philosophy of Science, eds. Lynn Henkinson Nelson and Jack Nelson, 39-58. Dordrecht: Kluwer.

Luhmann, Niklas. 1995. Social Systems. Stanford: Stanford University Press.

Luukkonen, Terttu. 2012. Conservatism and risk-taking in peer review: Emerging ERC practices. Research Evaluation. https://doi.org/10.1093/reseval/rvs001.

Maliniak, Daniel, Susan Peterson, Ryan Powers, and Michael J. Tierney. 2018. Is International Relations a Global Discipline? Hegemony, Insularity, and Diversity in the Field. Security Studies. https://doi. org/10.1080/09636412.2017.1416824.

Merton, Robert K. 1973. The Normative Structure of Science. In The Sociology of Science, ed. Robert K. Merton, 267-278. Chicago: The University of Chicago Press.

Metzger, Walter P. 1978. Academic Freedom and Scientific Freedom. Daedalus 107: 93-114.

Mills, John Stuart. 1992. On Liberty. Cambridge: Cambridge Unviersity Press.

Moore, Don A., and George Loewenstein. 2004. Self-Interest, Automaticity, and the Psychology of Conflict of Interest. Social Justice Research. https://doi.org/10.1023/B:SORE.0000027409.88372.b4.

Moyi Okwaro, Ferdinand, and P.W. Geissler. 2015. In/dependent Collaborations: Perceptions and Experiences of African Scientists in Transnational HIV Research. Medical Anthropology Quarterly. https://doi.org/10.1111/maq.12206.

Moynihan, Ray, and Lisa Bero. 2017. Toward a Healthier Patient Voice: More Independence Less Industry Funding. JAMA Internal Medicine. https://doi.org/10.1001/jamainternmed.2016.9179.

Müller, Rainer Albert, and Rainer C. Schwinges (eds.). 2008. Wissenschaftsfreiheit in Vergangenheit und Gegenwart. Basel: Schwabe.

Munder, Thomas, Oliver Brütsch, Rainer Leonhart, Heike Gerger, and Jürgen Barth. 2013. Researcher allegiance in psychotherapy outcome research: an overview of reviews. Clinical Psychology Review. https://doi.org/10.1016/j.cpr.2013.02.002.

Murray, Fiona, and Scott Stern. 2007. Do formal intellectual property rights hinder the free flow of scientific knowledge? An empirical test of the anti-commons hypothesis. Journal of Economic Behavior \& Organization. https://doi.org/10.1016/j.jebo.2006.05.017.

Murray, Fiona, Philippe Aghion, Mathias Dewatripont, Julian Kolev, and Scott Stern. 2016. Of mice and academics: Examining the effect of openness on innovation. American Economic Journal: Economic Policy. https://doi.org/10.1257/pol.20140062.

Nagel, Anne C. 2012. Hitlers Bildungsreformer. Das Reichsministerium für Wissenschaft, Erziehung und Volksbildung 1934-1945. Frankfurt am Main: Fischer Taschenbuch Verlag.

Nelson, Richard R. 1959. The Simple Economics of Basic Scientific Research. Journal of Political Economy. https://doi.org/10.1086/258177. 
Neufeld, Michael J. 1995. The Rocket and the Reich: Peenemünde and the Coming of the Ballistic Missile Era. New York: The Free Press.

Oreskes, Naomi, and Erik M. Conway. 2010. Merchants of Doubt: How a Handful of Scientists Obscured the Truth on Issues from Tobacco Smoke to Global Warming. London: Bloomsbury Press.

Pannucci, Christopher J., and Edwin G. Wilkins. 2010. Identifying and Avoiding Bias in Research. Plastic and Reconstructive Surgery. https://doi.org/10.1097/PRS.0b013e3181de24bc.

Panofsky, Aaron. 2011. Generating sociability to drive science: Patient advocacy organizations and genetics research. Social Studies of Science. https://doi.org/10.1177/0306312710385852.

Pritchard, Rosalind M. O. 1998. Academic freedom and autonomy in the United Kingdom and Germany. Minerva 36: 101-124.

Proctor, Robert N. 1999. The Nazi War on Cancer. Princeton: Princeton University Press.

Proctor, Robert N. 2012. Golden Holocaust: Origins of the Cigarette Catastrophe and the Case for Abolition. Berkeley: University of California Press.

Radder, Hans (ed.). 2010. The Commodification of Academic Research: Science and the Modern University. Pittsburgh: University of Pittsburgh Press.

Rappert, Brian, Brian Balmer, and John Stone. 2008. Science, Technology, and the Military: Priorities, Preoccupations, and Possibilities. In The Handbook of Science and Technology Studies, eds. Edward J. Hackett, Olga Amsterdamska, Michael Lynch, and Judy Wajcman, 719-739. Cambridge: MIT Press.

Rectors' Conferences. 2018. Universities for Enlightenment. https://www.hrk.de/press/press-releases/ press-release/meldung/vienna-declaration-european-rectors-conferences-make-the-case-for-acade mic-freedom-and-university/. Accessed 2 June 2021.

Resnik, David B. 1998. The Ethics of Science: An Introduction. New York and London: Routledge.

Resnik, David B. 2007. The Price of Truth: How Money Affects the Norms of Science. Oxford: Oxford University Press.

Resnik, David B. 2009. Playing Politics with Science: Balancing Scientific Independence and Government Oversight. Oxford: Oxford University Press.

Reuter, Astrid. 2014. Religion in der verrechtlichten Gesellschaft: Rechtskonflikte und öffentliche Kontroversen um Religion als Grenzarbeiten am religiösen Feld. Göttingen: Vandenhoeck \& Ruprecht.

Rip, Arie. 1994. The Republic of Science in the 1990s. Higher Education. https://doi.org/10.1007/ BF01383569.

Rooney, Phyllis. 1992. On Values in Science: Is the Epistemic/Non-Epistemic Distinction Useful? In PSA: Proceedings of the Biennial Meeting of the Philosophy of Science Association. https://doi. org/10.1086/psaprocbienmeetp.1992.1.192740.

Schimank, Uwe. 2005. 'New Public Management' and the academic profession: Reflections on the German situation. Minerva. https://doi.org/10.1007/s11024-005-2472-9.

Schott, Gisela, Henry Pachl, Ulrich Limbach, Ursula Gundert-Remy, Wolf-Dieter Ludwig, and Klaus Lieb. 2010a. The financing of drug trials by pharmaceutical companies and its consequences. Part 1: a qualitative, systematic review of the literature on possible influences on the findings, protocols, and quality of drug trials. Deutsches Ärzteblatt International. https://doi.org/10. 3238/arztebl.2010.0279.

Schott, Gisela, Henry Pachl, Ulrich Limbach, Ursula Gundert-Remy, Klaus Lieb, and Wolf-Dieter Ludwig. 2010b. The financing of drug trials by pharmaceutical companies and its consequences: part 2: a qualitative, systematic review of the literature on possible influences on authorship, access to trial data, and trial registration and publication. Deutsches Ärzteblatt International. https://doi.org/10.3238/arztebl.2010.0295.

Shibayama, Sotaro, and Yasunori Baba. 2015. Dishonest conformity in peer review. Prometheus. https://doi.org/10.1080/08109028.2015.1114745.

Simmons, Joseph P., Leif D. Nelson, and Uri Simonsohn. 2011. False-Positive Psychology: Undisclosed Flexibility in Data Collection and Analysis Allows Presenting Anything as Significant. Psychological Science. https://doi.org/10.1177/0956797611417632.

Smith, Richard, and Jane Blazeby. 2018. Why religious belief should be declared as a competing interest. BMJ. https://doi.org/10.1136/bmj.k1456.

Solomon, Miriam. 2015. Making Medical Knowledge. Oxford: Oxford University Press.

Stanley, T.D. 2005. Beyond Publication Bias. Journal of Economic Surveys. https://doi.org/10.1111/j. 0950-0804.2005.00250.x. 
Star, Susan Leigh, and James R. Griesemer. 1989. Institutional Ecology, 'Translations' and Boundary Objects: Amateurs and Professionals in Berkeley's Museum of Vertebrate Zoology, 1907-39. Social Studies of Science. https://doi.org/10.1177/030631289019003001.

Steel, Daniel. 2010. Epistemic Values and the Argument from Inductive Risk. Philosophy of Science. https://doi.org/10.1086/650206.

Stegenga, Jacob. 2018. Medical Nihilism. Oxford: Oxford University Press.

Stichweh, Rudolf. 2014. Paradoxe Autonomie. Zu einem systemtheoretischen Begriff der Autonomie von Universität und Wissenschaft. In Autonomie revisited. Beiträge zu einem umstrittenen Grundbegriff in Wissenschaft, Kunst und Politik. Zeitschrift für Theoretische Soziologie, 2. Sonderband, eds. Martina Franzen, Arlena Jung, David Kaldewey and Jasper Korte, 29-40. Weinheim: Beltz Juventa.

Stoll, Marlene, Alexander Mancini, Lara Hubenschmid, Nadine Dreimüller, Jochem König, Pim Cuijpers, Jürgen. Barth, and Klaus Lieb. 2020. Discrepancies from registered protocols and spin occurred frequently in randomized psychotherapy trials:-A meta-epidemiologic study. Journal of Clinical Epidemiology. https://doi.org/10.1016/j.jclinepi.2020.08.013.

Storer, Norman W. 1966. The Social System of Science. New York: Holt, Rinehart and Winston.

Sutton, John R. 1984. Organizational Autonomy and Professional Norms in Science: A Case Study of the Lawrence Livermore Laboratory. Social Studies of Science. https://doi.org/10.1177/03063 1284014002002.

Szöllösi-Janze, Margit (ed.). 2001. Science in the Third Reich. Oxford and New York: Berghahn Books.

Teixeira, Pedro, Ben Jongbloed, Alberto Amaral, and David Dill. 2004. Introduction. Markets in Higher Education: Rhetoric or Reality. In Markets in Higher Education: Rhetoric or Reality, eds. Pedro Teixeira, Ben Jongbloed, David Dill and Alberto Amaral, 1-12. Dordrecht: Kluwer.

Thompson, Dennis F. 2009. The Challenge of Conflict of Interest in Medicine. Zeitschrift Für Evidenz, Fortbildung und Qualität im Gesundheitswesen. https://doi.org/10.1016/j.zefq.2009.02. 021.

Tickner, Arlene B., and Ole Wæver (eds.). 2009. International Relations Scholarship Around the World. London: Routledge.

Travis, G.D.L., and H.M. Collins. 1991. New Light on Old Boys: Cognitive and Institutional Particularism in the Peer Review System. Science, Technology, \& Human Values. https://doi.org/10. $1177 / 016224399101600303$.

Tullock, Gordon. 1980. Efficient rent seeking. In Toward a Theory of Rent Seeking Society, eds. James M. Buchanan, Robert D. Tollinson and Gordon Tullock, 97-112. College Station: Texas A\&M University Press

Van Long, Ngo. 2015. The theory of contests: A unified model and review of the literature. In Companion to the Political Economy of Rent Seeking, eds. Roger D. Congleton and Arye L. Hillman, 19-52. Cheltenham: Edward Elgar.

Van't Veer, Anna Elisabeth, and Roger Giner-Sorolla. 2016. Pre-registration in social psychology-A discussion and suggested template. Journal of Experimental Social Psychology. https://doi.org/ 10.1016/j.jesp.2016.03.004.

Varma, Roli, and Meghna Sabharwal. 2018. International Collaboration: Experiences of Indian Scientists and Engineers after Returning from the United States. Perspectives on Global Development. https://doi.org/10.1163/15691497-12341498.

Vaughan, Liwen, Wolfgang Glänzel, Christopher Korch, and Amanda Capes-Davis. 2017. Widespread use of misidentified cell line KB (HeLa): Incorrect attribution and its impact revealed through mining the scientific literature. Cancer Research. https://doi.org/10.1158/0008-5472. Can-16-2258.

Walker, Mark. 2012. The 'National' in international and transnational science. British Journal for the History of Science. https://doi.org/10.1017/S0007087412000398.

Walker, Mark, and Monika Renneberg (eds.). 1994. Science, Technology and National Socialism. Cambridge: Cambridge University Press.

Wallace, Matthew L., and Ismael Ràfols. 2018. Institutional shaping of research priorities: A case study on avian influenza. Research Policy. https://doi.org/10.1016/j.respol.2018.07.005.

Wang, Jessica. 1999. American Science in an Age of Anxiety. Science, Anti-Communism, and the Cold War. Chapel Hill: University of North Carolina Press. 
Wang, Jessica. 2002. Scientists and the Problem of the Public in Cold War America, 1945-1960. In Science and Civil Society, eds. Lynn K. Nyhart and Thomas H. Broman, 323-347. Osiris. https://doi.org/10.1086/649368.

Weingart, Peter. 2014. Die Stellung der Wissenschaft im demokratischen Staat. Freiheit der Wissenschaft und Recht auf Forschung im Verfassungsrecht. In Autonomie revisited. Beiträge zu einem umstrittenen Grundbegriff in Wissenschaft, Kunst und Politik. Zeitschrift für Theoretische Soziologie, 2. Sonderband, eds. Martina Franzen, Arlena Jung, David Kaldewey and Jasper Korte, 305-329. Weinheim: Beltz Juventa

Weindling, Paul (ed.). 2017. From Clinic to Concentration Camp: Reassessing Nazi Medical and Racial Research, 1933-1945. New York: Routledge/Taylor and Francis.

Weiss, Sheila Faith. 2010. The Nazi Symbiosis: Human Genetics and Politics in the Third Reich. Chicago: University of Chicago Press.

Whitley, Richard, Jochen Gläser, and Lars Engwall (eds.). 2010. Reconfiguring Knowledge Production: Changing authority relationships in the sciences and their consequences for intellectual innovation. Oxford: Oxford University Press.

Whitley, Richard, and Jochen Gläser. 2014. The Impact of Institutional Reforms on the Nature of Universities as Organisations. In Organizational Transformation and Scientific Change: The Impact of Institutional Restructuring on Universities and Intellectual Innovation, eds. Richard Whitley and Jochen Gläser, 19-49. Emerald Group: Bingley.

Whitley, Richard, Jochen Gläser, and Grit Laudel. 2018. The impact of changing funding and authority relationships on scientific innovations. Minerva 56(1): 109-134. https://doi.org/10.1007/ s11024-018-9343-7.

Wilholt, Torsten. 2009. Bias and values in scientific research. Studies in History and Philosophy of Science Part A. https://doi.org/10.1016/j.shpsa.2008.12.005.

Wilholt, Torsten. 2010. Scientific Freedom: Its Grounds and Their Limitations. Studies in History and Philosophy of Science Part A. https://doi.org/10.1016/j.shpsa.2010.03.003.

Wilholt, Torsten. 2012. Die Freiheit der Forschung: Begründungen und Begrenzungen. Frankfurt am Main: Suhrkamp.

Winsberg, Eric. 2018. Philosophy and Climate Science. Cambridge: Cambridge University Press.

Zarin, Deborah A., and Tony Tse. 2008. Moving Toward Transparency of Clinical Trials. Science. https://doi.org/10.1126/science.1153632.

Zechlin, Lothar. 2017. Wissenschaftsfreiheit und Organisation. Die "Hochschullehrermehrheit" im Grundrechtsverständnis der autonomen Universität. Ordnung der Wissenschaft. https://doi.org/10. 17176/20190211-102652-0.

Publisher's Note Springer Nature remains neutral with regard to jurisdictional claims in published maps and institutional affiliations. 